\title{
Laser mot uspesifikke nakkesmerter
}

\author{
Laserbehandling kan være nyttig sup- \\ plement til annen intervensjon ved \\ uspesifikke nakkesmerter. Det viser \\ en ny systematisk oversiktsartikkel.
}

Uspesifikke nakkesmerter rammer $10-24 \%$ av befolkningen i løpet av livet. Man antar at smertene stammer fra nakkesøylens ledd og musklene i nakken/skulderbuen. De ledsages ofte av spenningshodepine. Mest effektivt er øvelsesbehandling og manuell terapi, mens det er mangelfull dokumentasjon for legemiddelbehandling, ifølge kliniske retningslinjer.

Lavenergi laserbehandling er sjelden nevnt som alternativ $i$ kliniske retningslinjer for nakkesmerter. Den nye oversiktsartikkelen er skrevet av fire forskere, under- tegnede er seniorforfatter (1). Metaanalysen omfattet 16 randomiserte, kontrollerte studier med 820 pasienter med akutte eller kroniske uspesifikke nakkesmerter. 14 av studiene var av god til meget god kvalitet.

For akutte nakkesmerter viste to studier blandede resultater, mens ved kroniske nakkesmerter var sjansen for forbedring fire ganger høyere etter aktiv laserbehandling enn etter placebolaser. Smerteintensiteten for kroniske nakkesmerter, målt på en $100 \mathrm{~mm}$ VAS-skala ved behandlingsslutt, avtok 20 $\mathrm{mm}$ mer etter aktiv laserbehandling enn etter placebolaser. Effekten holdt seg i opptil 22 uker etter endt behandling, og bivirkningene av aktiv laserbehandling var ikke signifikant forskjellig enn dem etter placebolaser. Det var også klinisk relevante tilleggseffekter av laser brukt sammen med andre anbefalte terapiformer, f.eks. øvelsesbehandling.
Metaanalysene ble i tillegg brukt til å identifisere optimale doser og behandlingsprosedyrer. I studiene var det brukt i gjennomsnitt ti behandlingstimer og pasienten møtte 3-5 ganger per uke. Hver behandlingstime besto av laserbehandling rettet mot i gjennomsnitt 11 ømme punkter i musklene i skulder/nakke og nakkesøylens bueledd.

\section{Jan Magnus Bjordal \\ jan.magnus.bjordal@hib.no \\ Institutt for fysioterapi \\ Høgskolen i Bergen}

\section{Litteratur}

1. Chow RT, Johnson MI, Lopes-Martins RA et al. Efficacy of low-level laser therapy in the management of neck pain: a systematic review and metaanalysis of randomised placebo or active-treatment controlled trials. Lancet 2009; 374 : 1897-908.

\section{Bak-genet involvert i hørselstap}

Aldersrelatert hørselstap er et resultat av at de sensoriske hårcellene og nevronene $i$ det indre øret dør. Ifølge tidligere forskning kan slike aldersrelaterte endringer bl.a. skyldes at reaktive oksygenforbindelser forårsaker mutasjoner i mitokondrienes DNA.

Nye forskningsresultater antyder at det mitokondrielle proteinet Bak kan være involvert i denne prosessen (Proc Natl Acad Sci USA 2009; 106: 19432-7). En forskergruppe har nå vist at mus uten det mitokondrielle proapoptotiske genet Bak har mindre grad av aldersrelatert hørselstap. De testet hørselen hos fem og 15 måneder gamle genmodifiserte mus uten Bak-proteinet.

Bak er et protein som blir aktivert av oksidativt stress. Forskerne viste også at medikamentell nedregulering av genet reduserte hørselstapet.

\section{Er kvinnen beskyttet mot hiv når mannen er omskåret?}

Det er vist at mannlig omskjæring gir indirekte beskyttelse hos kvinner ved at det reduserer heteroseksuelle menns risiko for hivinfeksjon (Lancet Infect Dis 2009; 9: 669-77). For å finne en eventuell direkte effekt av mannlig omskjæring gjennomførte en forskergruppe en metaanalyse av én randomisert, kontrollert studie og seks longitudinelle analyser. Dette viste at mannlig omskjæring ikke gir noen direkte redusert hivrisiko hos kvinner (summert RR 0,80; $95 \%$ KI 0,53-1,36).

\section{Bilateral eller unilateral lungetransplantasjon?}

\section{Pasienter med terminal lungesvikt får i økende grad utført bilateral lunge- transplantasjon.}

Det er uklart hvorfor et økende antall pasienter med idiopatisk lungefibrose og terminal lungesvikt får utført bilateral fremfor unilateral lungetransplantasjon. Randomiserte studier foreligger ikke.

I perioden 1987-2009 fikk 3327 pasienter med idiopatisk lungefibrose utført lungetransplantasjon i USA, hvorav 36\% var bilateral lungetransplantasjon (1). Median overlevelsestid var lengre etter bilateral transplantasjon enn etter unilateral (5,2 år versus 3,8 år), men det var ingen forskjell etter justeringer for preoperative forskjeller. Forfatterne konkluderer med at bilateral lungetransplantasjon gir flere tidlige komplikasjoner, men bedre overlevelse på lengre sikt. Tilsvarende gir unilateral lungetransplantasjon bedre overlevelse på kort sikt, men risikoen for senkomplikasjoner er økt.

- Andelen bilaterale lungetransplantasjoner er økende også i Norge, og det samme gjelder langtidsoverlevelsen, sier overlege Øystein Bjørtuft ved Lungemedisinsk avdeling, Oslo universitetssykehus, Rikshospitalet. - Denne undersøkelsen gir ny kunnskap om premissene for valget mellom bilateral og unilateral transplantasjon.

Pasienter med idiopatisk lungefibrose, dvs. fibroserende alveolitt,

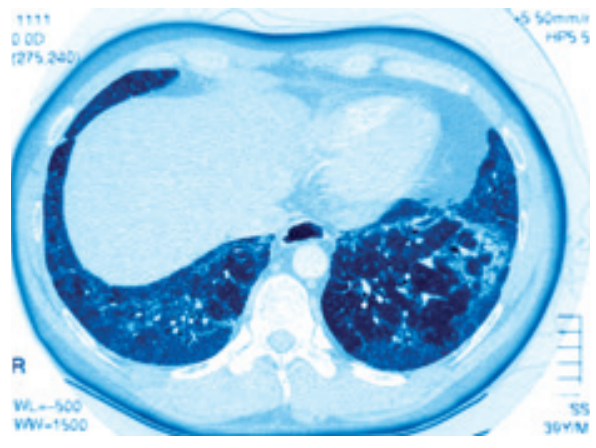

Idiopatisk lungefibrose. Illustrasjonsfoto (C) James Cavallini/Photo Researchers/GV-Press/NordicPhotos

har ofte liten nytte av medisinsk behandling, og dødeligheten er høy. Disse bør derfor henvises og lungetransplanteres tidligere i sykdomsforløpet. Donortilgangen er imidlertid begrenset, noe som bidrar til vanskelige medisinske og etiske vurderinger, sier Bjørtuft.

\section{Petter Gjersvik}

petter.gjersvik@legeforeningen.no Tidsskriftet

\section{Litteratur}

1. Thabut G, Chrisie JD, Ravaud P et al. Survival after bilateral versus single-lung transplantation for idiopathic pulmonary fibrosis. Ann Intern Med 2009; 151: 767-74. 